\title{
カスケード方式に基づく直列配置された 流水型ダム群の洪水制御能力の評価 ESTIMATION OF FLOOD CONTROL CAPABILITY OF MULTIPLE DRY DAMS CONSTRUCTED IN SERIES BASED ON CASCADE METHOD
}

\author{
押川英夫 1 - 小松利光 ${ }^{2}$ \\ Hideo OSHIKAWA and Toshimitsu KOMATSU \\ 1正会員 博（工） 九州大学大学院助教 工学研究院環境社会部門（干819-0395 福岡市西区元岡744） \\ 2 フェロー 工博 九州大学大学院特命教授・名誉教授 工学研究院環境社会部門（同上）
}

\begin{abstract}
A new flood control concept called 'Cascade method' which permits multiple dams around an upstream region in a river basin to overflow from their emergency spillways has been suggested. In this study, Cascade method was compared with a conventional flood control method under conditions that multiple dry dams have the same reservoir capacity in order to understand the flood control mechanism of Cascade method. In the conventional method, upstream dams transform flood hydrograph horizontally and remain its peak partially at an end of the flood. Therefore, a downstream dam has to function again in order to reduce the remained peak. On the other hand, multiple dams in Cascade method transform the hydrograph vertically and reduce its peak linearly. In addition, empirical formulas were established to estimate quantitatively the flood control capability of multiple dry dams constructed in series in Cascade method.
\end{abstract}

Key Words : Cascade method, dry dam, flood control, overflow, empirical formula

\section{1.はじめに}

近年地球温暖化によると思われる災害外力の増大が実 感されるようになってきた.今後も温暖化による様々な 影響が顕在化してくると考えられ，大規模超過洪水によ る水・土砂災害の発生も危惧されている1). しかしなが ら，我が国の社会・防災基盤は高度経済成長期に整備さ れたものが多く，その大部分は老朽化しつつある。ごく 最近では国土強鞋化が一部で叫ばれるようになっている ものの，世界的な不況の影響もあり，大規模な防災施設 の新設や積極的な施設更新が中長期的に続くとは考えに $く<$, 既存施設の有効利用などの智恵を絞った防災対策 が今後益々必要になってくるものと考えられる.

このような背景の下で，我々は今後増大するであろう 災害外力と社会の望む自然環境の保全に同時に対応して いかなければならない，特に日本では，今時の震災特需 を別とした公共事業費の著しい削減や環境への影響に対 する危惧感から，ダム建設に代表される大規模な公共工 事の実施は極めて困難になってきており，今後は小規模 なインフラが重要視されるものと考えられる. そのよう
な中，近年流水型（穴あき）ダムの機能が見直され，島 根県の益田川ダム・鹿児島県の西之谷ダムに代表される ように各地で計画されて既に施工されるまでになってき た2) 4). しかしながら，本格的な治水専用ダムとしての例 は少なく, 幾つかの課題も指摘されていることから5), 6), 今後の研究成果の蓄積による問題解決が望まれている.

このような状況の下，押川ら7は直列に配置されたダ ム群を有する流域において有効な “ダムの水が（非常用 洪水吐きを通して）溢れることを許容する”という新し い治水の概念を提案している．従来のダムによる治水の 考え方は, 直列に配置されている場合であっても, 個々 のダムで（下流の河道に応じた）計画高水流量を定め, それぞれのダムが溢れないように洪水処理を行うもので ある. 著者ら 7〜11は，このような従来の考え方に基づい て配置された流水型ダム群（以後，従来型と呼ぶ）と， 上記の新しい概念に基づき配置された同じスケールの流 水型ダム群（以後, 越流型もしくはカスケード方式と呼 ぶ）において，洪水制御能力がどのように異なるのかを 比較した，その結果，直列配置された流水型ダム群にお いて，山間部に位置する上流側のダムで非常用洪水吐き からの放流を許容することで，一般的にはより重要な下 
流側流域のための洪水制御能力が顕著に強化されること を明らかにした. 更に, 通常の貯水型ダム群においても それらのゲートの操作方法を変えることで, 直列配置さ れた流水型ダム群と同様に洪水制御能力が強化されるこ とについても明らかにしている7,11).

これまでの研究7フ 11)により, 越流型の洪水制御方式を 採用することで，従来型と比較して洪水制御能力が強化 されることが明らかとなってきた. 今後のカスケード方 式の実用化にあたっては，実水域に本方式を適用した場 合の具体的な効果の予測が必要となる.しかしながら, これまでの限られた条件の数值解析や室内実験に基づい た結果では，カスケード方式の洪水制御能力の定量的な 検討・評価が出来ていなかった，そこで，前報11)で示し た従来型と越流型の洪水制御能力の差異の $2 つ の$ 要因

[11従来型で行われている2度手間な洪水制御が越流型 では行われない，(2)洪水波形の前傾化］の内，主因とな る(1について，更に平易な解釈を試みるとともに，解析 条件を系統的に変えた数值シミュレーションを行うこと により，カスケード方式の洪水制御効果を定量的に推定 するための簡便な評価式の導出を試みた.

\section{2. シミュレーションの概要と計算条件}

\section{（1）シミュレーションの概要}

複数のダムが連続的に配置された対象流域において, ここでは簡単のために上流側からの流入量以外に降雨や 支川からの流入等はないと仮定した. また，後述の結果 から明らかなように, 本研究ではダムからの顕著なオー バーフロー（堤体上部の非常用洪水吐きからの越流）が 頻繁に生じる. しかしながら本研究のダム群は, 上流の 山間河川部で河川水位の上昇や越水をある程度許容でき る箇所での設置を想定しているので，越流型ではダム群 の設置領域全体を実質的な河道内遊水池 ${ }^{22}$ と見なしてお り，最下流のダムからの越流のみが問題となる.

本研究では, 細田による一次元の常流・射流混在流れ を解析するコード13)適宜修正して用いており，基本的 には押川ら99,11)が用いたものと同じである．基礎式は以 下の連続の式(1)と一次元の運動方程式(2)である.

$$
\begin{gathered}
\frac{\partial A}{\partial t}+\frac{\partial Q}{\partial x}=0 \\
\frac{\partial Q}{\partial t}+\frac{\partial u Q}{\partial x}+g A \frac{\partial z_{s}}{\partial x} \cos \theta=-\frac{g A n^{2}}{R^{4 / 3}} u|u|
\end{gathered}
$$

ここに, $Q$ : 流量, $A$ : 流水断面積, $u$ : 流下方向の断面 平均流速, $z_{s}$ : 基準水平面加らの水位, $R$ : 径深, $g$ : 重 力加速度, $x$ : 流下方向の空間座標, $t$ : 時間, $\theta$ : 河床 $\left(x\right.$ 軸）と水平面のなす角度, $n\left[=0.03\left(\mathrm{~m}^{-1 / 3} \mathrm{~s}\right)\right]$ : Manningの粗度係数である.

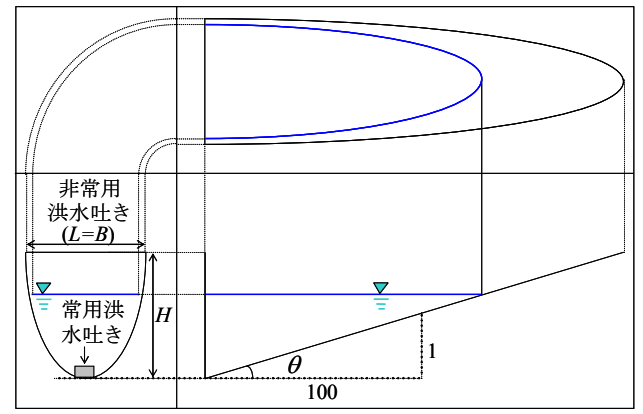

図-1 対象とする流水型ダムの概略図

本研究では，堤体の強度は十分なものとして検討しな いことから，計算上のダム堤体は薄い不透過壁とした. 直列配置された複数のダムの効果の比較を容易にするた め, 対象とするダムの断面形状は（常用洪水吐きの断面 積を除いて）全て同一としており，堤高 $H$ て堤頂長 $L の 2$ 次関数形である (図-1参照)。ここでは2次関数断面の ダムの底部を河道として河川水が流下寸るものとする. 河床勾配 $\tan \theta$ は 0.01 である. 河床の常用洪水吐き（穴 あきダムの “穴” ) の断面積 $A_{b}$ は，ダム前面の水位が堤 高 $H$ と等しくなった時点で放流量が（ダム下流側の）計 画高水流量 $Q_{a}$ に等しくなるように設計した. 常用洪水吐 きからの放流量 $Q_{\text {outb }}$ は， $A_{b}$ がダム前面の流水断面積と 比べて十分に小さいと考え, トリチェリの定理からその 時点での水位によって決定されると仮定した. また, 各 ダムの非常用洪水吐きについては，クレスト自由越流形 式のゲートレスダム（いわゆる“坊主ダム”）を対象と しており（図-1参照），越流流量の計算には越流公式 $Q_{\text {out-u }}=K B h^{3 / 2}$ を用いた ${ }^{14)}$. ここでB は越流幅, $h$ は越流水 深（非常用洪水吐きのクレストからの貯水位）， $K$ は流 量係数であり, 越流する際は全幅で越流寸る $(B=L)$. 各 ダムからの総放流量は $Q_{o u t}=Q_{o u t-b}+Q_{o u t-u}$ である. また, 簡単のために堆砂容量等は無視している.

流下方向の計算領域は $L_{x A}=200(\mathrm{~km})$ で, 今後は特に断 らない限り，等間隔の50(km)，100(km)，150(km)の3箇 所に同じ大きさの流水型ダムが設置された流域を対象と する. 寸なわち, ダム間距離は $L_{x d}=50(\mathrm{~km})$ である. 計算 格子間隔は $1.0(\mathrm{~km})$, 流下方向の計算格子数は 200 , 時間 格子間隔は $\Delta t=1.0(\mathrm{~s})$, 計算時間は条件に応じて変更して おり，初期条件と同じ等流状態に回復する時間を設定し ている（72時間以上）。

境界条件となる計算領域の上流端で発生する洪水の流 入流量 $Q_{i n}$ には，一山洪水を示す以下の式(3)を与えた ${ }^{13)}$.

$$
Q_{i n}(t)=Q_{b}+\left(Q_{p}-Q_{b}\right)\left\{\frac{t}{t_{p}} \exp \left(1-\frac{t}{t_{p}}\right)\right\}^{c}
$$

ここで, $t_{p}(=30 \mathrm{hr})$ は洪水のピーク到達時間， $Q_{b}$ は河川の 平常流量, $Q_{p}$ は洪水のピーク流量, $c$ は洪水波形に関す る定数である.下流端の境界条件にはノイマン条件, 初 期条件としては $Q_{b}$ を基にした等流の条件を与えている. 


\section{（2）計算条件の詳細}

本研究では，カスケード方式の洪水制御能力の定量評 価を目指しているため，洪水波形（ハイドログラフ）を 系統的に変化させた上で，従来型と越流型の洪水制御効 果を比較・検討した. 具体的には, 流水型ダムに流入し てくる洪水の規模（洪水の総量，以降では $\Sigma Q I N$ と表記 する）が同じ条件の下で，式(3)の $Q_{p}$ および係数 $c$ を適宜 変えることで，洪水の規模が同じで波形のみが異なる八 イドログラフを実現した (CaseAおよびCaseB)。なお, $\Sigma Q I N は Q_{b}$ を除いた $Q_{i n}$ の長時間の積分值で，次式で表現 される(本研究では $\left.T_{\infty}=178 \mathrm{hr}\right)$.

$$
\Sigma Q I N=\int_{t=0}^{t=\infty}\left\{Q_{i n}(t)-Q_{b}\right\} d t \fallingdotseq \sum_{t=0}^{T_{\infty}}\left\{Q_{i n}(t)-Q_{b}\right\} \Delta t
$$

洪水波形の条件を主要なダムの諸量と併せて表-1に示す.

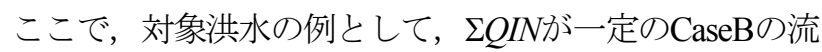
入八イドログラフの例を図-2に示寸．更なる計算条件と して, 流入洪水の波形はCaseB (CaseB1〜CaseB9) と同 じで，設置するダムの大きさ $(H$ と $L)$ を変えた場合を CaseC, CaseD, CaseE とした（各Caseで9通り）.c=20の 場合を例に, CaseAからCaseEの主な計算条件を表-2に 示寸. ただし, $V$ はダム1基の貯水容量である.

\section{3. カスケード方式の洪水制御能力の評価}

\section{（1）カスケード方式の基本的な洪水制御能力}

始めに, 以降の検討の参考として, CaseB5を対象に押 川ら7, 9), 11)が行ったような従来型と越流型の 3 基の流水型 ダム群による洪水制御の比較を行う。まず，従来型の洪 水制御に基づいて，3基全てのダムが越流しない限界の 計画高水流量 $Q_{a i}$ (各常用洪水吐きの断面積に対応， $i$ は 上流側からのダムの番号) を求めた。 その結果， $Q_{a l}$ $=4200\left(\mathrm{~m}^{3} / \mathrm{s}\right), Q_{a 2}=3300\left(\mathrm{~m}^{3} / \mathrm{s}\right), Q_{a 3}=2648\left(\mathrm{~m}^{3} / \mathrm{s}\right)$ となった.

次に, 越流型の場合の例として, 上流側から下流側ま で $Q_{a}$ を一定とした場合 $\left(Q_{a l}=Q_{a 2}=Q_{a 3}=Q_{a}\right)$ で，下流側ダム からの越流が生じない限界を求めたところ， $Q_{a}=1798$ $\left(\mathrm{m}^{3} / \mathrm{s}\right)$ が得られた. CaseB5の越流型と従来型の放流量の 時系列 $Q_{\text {outi }}$ を流入洪水之併せて図-3に示寸，越流型では $Q_{3 M a x}=Q_{a}=1798\left(\mathrm{~m}^{3} / \mathrm{s}\right)$ であることから，従来型の $Q_{3 M a x}=Q_{a 3}=2648\left(\mathrm{~m}^{3} / \mathrm{s}\right)$ と比較するとピークが $32 \%$ 小さく なっている．ただし， $Q_{i M a x}$ は各ダムからの最大放流量 である．この結果からも，越流型を採用寸ることで，従 来型よりも洪水制御能力が顕著に強化されることが理解 される. なお，これらの結果は過去の著者ら7), 9), 10, 11)の 検討結果（17〜 40\%の低減）と同程度となっている.

\section{（2）カスケード方式の洪水制御機構}

前報11)で著者らは，従来型と比較して越流型の洪水制 御能力が顕著に強化される主な理由を示した. それは, 「従来型では複数のダムで放流量のピークを徐々に低減
表-1 CaseA (CaseA1 CaseA8) とCaseB の計算条件

\begin{tabular}{|c|c|c|c|c|c|}
\hline Case No. & $Q_{p}\left[\mathrm{~m}^{3} / \mathrm{s}\right]$ & $c$ & $Q_{b}\left[\mathrm{~m}^{3} / \mathrm{s}\right]$ & $H[\mathrm{~m}]$ & $L[\mathrm{~m}]$ \\
\hline CaseA1 & 3000.0 & 2.6578 & 250.0 & 100.0 & 297.01 \\
\hline CaseA2 & 4000.0 & 4.8073 & 250.0 & 100.0 & 297.01 \\
\hline CaseA3 & 5000.0 & 7.6154 & 250.0 & 100.0 & 297.01 \\
\hline CaseA4 & 6000.0 & 11.083 & 250.0 & 100.0 & 297.01 \\
\hline CaseA5 & 7000.0 & 15.212 & 250.0 & 100.0 & 297.01 \\
\hline CaseA6 & 8000.0 & 20.000 & 250.0 & 100.0 & 297.01 \\
\hline CaseA7 & 9000.0 & 25.449 & 250.0 & 100.0 & 297.01 \\
\hline CaseA8 & 10000.0 & 31.558 & 250.0 & 100.0 & 297.01 \\
\hline CaseB1 & 2000.0 & 2.0675 & 200.0 & 100.0 & 269.32 \\
\hline CaseB2 & 3000.0 & 4.7860 & 200.0 & 100.0 & 269.32 \\
\hline CaseB3 & 4000.0 & 8.6788 & 200.0 & 100.0 & 269.32 \\
\hline CaseB4 & 5000.0 & 13.750 & 200.0 & 100.0 & 269.32 \\
\hline CaseB5 & 6000.0 & 20.000 & 200.0 & 100.0 & 269.32 \\
\hline CaseB6 & 7000.0 & 27.429 & 200.0 & 100.0 & 269.32 \\
\hline CaseB7 & 8000.0 & 36.037 & 200.0 & 100.0 & 269.32 \\
\hline CaseB8 & 9000.0 & 45.825 & 200.0 & 100.0 & 269.32 \\
\hline CaseB9 & 10000.0 & 56.791 & 200.0 & 100.0 & 269.32 \\
\hline
\end{tabular}

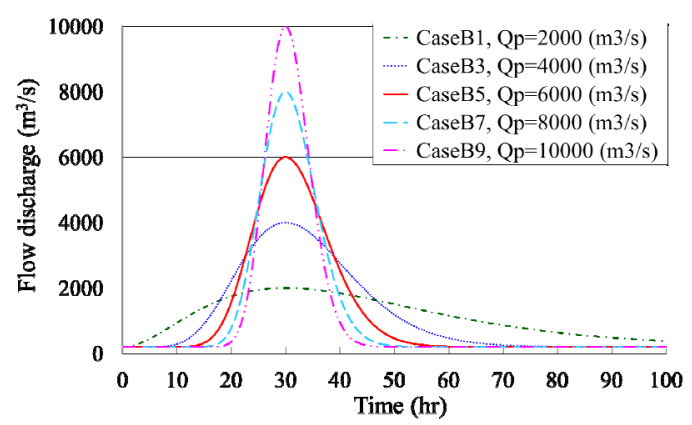

図-2 総流入量が同じ洪水波形の例 (CaseB)

表-2 各Caseの計算条件 ( $c=20$ の場合)

\begin{tabular}{|c|c|c|c|c|c|c|}
\hline Case No. & $c$ & $Q_{p}\left[\mathrm{~m}^{3} / \mathrm{s}\right]$ & $Q_{b}\left[\mathrm{~m}^{3} / \mathrm{s}\right]$ & $H[\mathrm{~m}]$ & $L[\mathrm{~m}]$ & $V\left[\mathrm{~m}^{3}\right]$ \\
\hline CaseA6 & 20.0 & 8000.0 & 250.0 & 100.0 & 297.01 & 79202731 \\
\hline CaseB5 & 20.0 & 6000.0 & 200.0 & 100.0 & 269.32 & 71818640 \\
\hline CaseC5 & 20.0 & 6000.0 & 200.0 & 90.0 & 200.00 & 43200000 \\
\hline CaseD5 & 20.0 & 6000.0 & 200.0 & 80.0 & 177.78 & 30340741 \\
\hline CaseE5 & 20.0 & 6000.0 & 200.0 & 110.0 & 224.87 & 72559383 \\
\hline
\end{tabular}

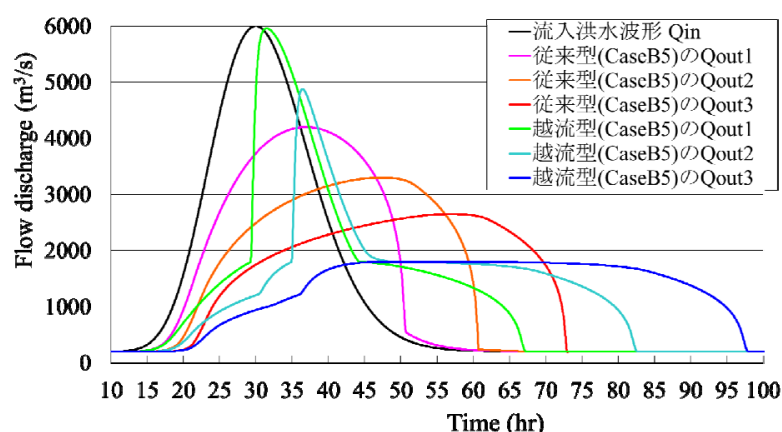

図-3 従来型と越流型のハイドログラフの比較（CaseB5）

することから，上流側や中間のダムでは（ピークをある 程度下げたとしても）洪水の後半部に必然的に（越流型 の計画高水流量よりも多くの）放流量を残すことになる。 しかしながら下流側のダムでは, 最終的に従来型で残し た部分の洪水も低減する必要があることから，洪水制御 としてはある意味で2度手間となる」というものであっ た ${ }^{11)}$. 逆にこの点を越流型から見ると，越流型では無駄 
な洪水制御を行わずに貯水容量を目一杯使用するという ことになる．ここで，従来型と越流型の洪水制御方式の 差異を簡単な概念図を用いて改めて説明することとする.

従来型では，複数のダムでピークを徐々に下げていく ことから，理想的には図-4に示寸ハイドログラフを横に 切るような洪水制御を行うことになる. この場合のダム は全て流水型ではなくゲートを有する貯水型で，堤体断 面全体が高さも含めて任意に調節可能なゲートとなって いる仮想的なダムである. なお，これらのダムは，著者 らが以前に報告している下流側に複数の流水型ダム，上 流側にゲート付きの貯水型ダムを 1 基だけ設置して，そ のゲート操作で洪水波形が変形する効果を調べた際の上 流側の貯水型ダムと同様なものと考えて良い7, 11). 従来 型では， $Q_{i n}$ の流入波形を 1 基目のダムで $Q_{\text {outl }}$ （赤の 1 点鎖 線），2基目のダムで $Q_{\text {out } 2}$ (青の破線），3基目のダムで $Q_{\text {out3 }}$ (緑の点線) に変形させている（囲われた部分の面 積は同じ）。その際，中央付近に斜線が重なっている箇 所（※の部分）が認められ, 従来型では2度手間な洪水 制御が行われていること（貯水容量の重複使用）が理解 される（1章の要因(1)）。なお，計算結果の図-3では流 下に伴う時間経過と洪水波形の変形（ピークの減衰）が 考慮されているため，それらが無視された図-4とは，洪 水波形，特に位相に差異があるように見えている.

一方，越流型では，理想的には図-5に示寸ハイドログ ラフを縦に切るような洪水制御を行うことになる．具体 的には，最下流のダム迄で落とすべき放流量 $\left(Q_{a 3}\right)$ に上流 側から低減しようとすることから, 従来型において徐々 に低減するために発生する※のような 2 度手間がなくな ると共に，低減しきれない洪水については非常用洪水吐 きから越流させる（波形の縦方向一の急増を伴う）こと で次のダムで早めに洪水処理を行うことになる（2)の洪 水波形の前傾化）。なお，基本的に面積（積分值）が等 しいことから理解されるように，越流型では時間方向に 引き伸ばされた洪水波形となる．因みに本節の説明では, 越流型に優位に働く越流水深の増加は考慮されていない ものの，押川らワの検討から分かるように，その効果は 本節の議論と比較して, それ程顕著なものではない.

\section{（3）ダムの数が異なる場合の結果と考察}

直列配置される流水型ダムの数 $(N)$ の効果について検 討する. ここでは, 前述のCaseB5, $N=3$ の従来型と越流 型との比較と同様の検討を行うこととし，N=1, 2,3 , 4のそれぞれの場合について，従来型および越流型の計 算を行った. すなわち, 従来型では上流側から溢れない 限界までそれぞれのダムの $Q_{a}$ を小くしており, 一方, 越流型では上流から下流のダムまで同一の $Q_{a}$ を最下流の ダムが溢れない限界まで小さくした場合である。計算領 域は $L_{x A}=200(\mathrm{~km})$ で一定とし，Nに応じて $L_{x A}$ を等分割する ようにダムを設置した場合について計算を行った，すな わち，N毎に $L_{x d}$ が異なっており，例えば $N=4$ のースで

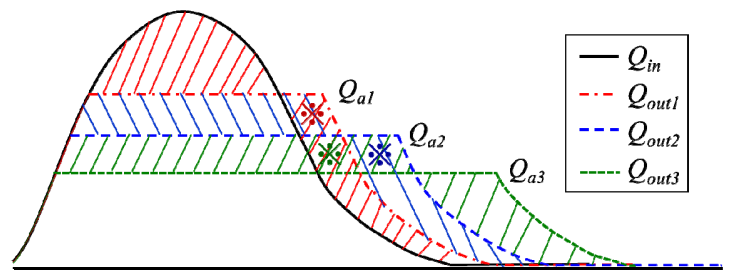

図-4 従来型の洪水制御の概念図

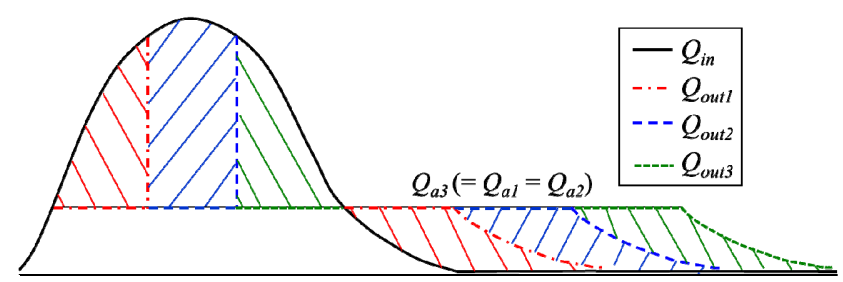

図-5 越流型（カスケード方式）の洪水制御の概念図

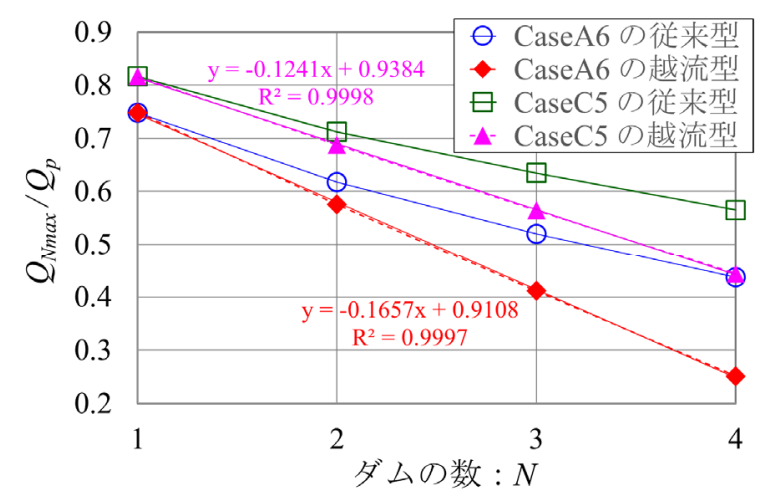

図-6 ダムの数と最下流のダムからの最大放流量の関係

は各ダム間で共通の $L_{x d}=40(\mathrm{~km})$ で $, x=40,80,120$, $160(\mathrm{~km})$ の箇所に同じ大きさのダムが設置されている. その他の条件はCaseB5の場合と同じである.

ここで，ダムの数が増えることによる従来型と越流型 の差異を比較した計算結果の例(CaseA6とCaseC5)を図-6 に示す. 横軸はダムの数 Nで, 縦軸は最下流のダムの最 大放流量 $Q_{N \max }$ を $Q_{p}$ で無次元化した值である. 後述され るように, 越流型には近似直線とその決定係数 $\left(\mathrm{R}^{2}\right)$ が 同色の数式で併記されている. 図-6の結果は著者らの以 前の結果》と同様な結果を示している. ダムが1基の場合 $(N=1)$ には，当然ながら従来型と越流型で一致してい るものの, CaseA6とCaseC5は共にNが増えるのに伴って, 従来型では $Q_{\text {Nmax }} / Q_{p}$ の減少率が小さくなっているのに対 し, 越流型では $Q_{N \text { max }} / Q_{p}$ が線形的に減少している。この 結果の差異が前節の無駄（要因(1) に相当したものであ り，越流型では貯水容量の使用の2度手間がないために, Nの増加に伴って線形的に効率良く洪水のピークカット を行っているものと考えられる（つまり，従来型が非線 形で非効率）。なお，CaseC5 と比較してCaseA6の効果

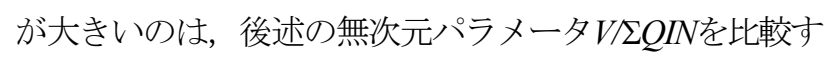
ると, CaseA6がCaseC5よりも大きいためである.

\section{（4）カスケード方式の洪水制御能力の定量評価}

本節では今後のカスケード方式の実用化を目指して, 
本解析によって得られた洪水制御効果を主要な無次元パ ラメータを用いて再現する簡便な評価式の導出を行った.

\section{a）洪水波形のピークの効果}

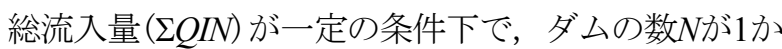
ら3のそれぞれの越流型の洪水制御結果に関して, 洪水 波形 $Q_{p}$ （および $c$ ）による $Q_{\text {Nmax }}$ の差異を比較した。 なお, 本節においても計算領域は $L_{x A}=200(\mathrm{~km})$ で一定であり, $N=3$ の場合は等間隔の $x=50(\mathrm{~km}), \quad 100(\mathrm{~km}), \quad 150(\mathrm{~km})$ の 3 箇所に同じ大きさの流水型ダムが設置されている. 一方, $N=2$ の場合は $x=50(\mathrm{~km}), \quad 100(\mathrm{~km})$ の箇所, $N=1$ の場合は $x=50(\mathrm{~km})$ の箇所に同じ大きさの流水型ダムが設置され

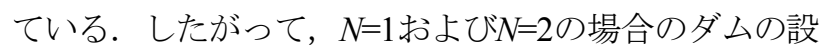
置位置が前節 (3) と異なっているものの, ダム間距離の 影響を検討した押川ら9の結果を考慮すると，それらの 差異の影響は小さいものと考えられる. その他の計算条 件はこれまでと同様である．ただし，前述のように $N=1$ は従来型と同一である.

一例として, 横軸に $Q_{p}$, 縦軸を $Q_{\text {Nmax }}$ としたCaseCの結 果を図-7に示す。これより，ダムの数に関わらず，洪水 波形のピークの増加に伴って $Q_{\text {Nmax }}$ は線形的に増加して いることが分かる．なお，図中には，以降の定式化で用 いる近似比例直線とその決定係数の結果を同色の数式で 併記している.

\section{b) 越流型の洪水制御能力の評価式の導出}

図一ー例示したような近似された比例関係を次式のよ うに表現する，なお， $\alpha$ は図-6の縦軸に相当している.

$$
Q_{N \max }=\alpha Q_{p}
$$

次に, CaseAからCaseEの全ての結果に関して，横軸を $N$, 縦軸を $\alpha$ とした結果を図-8に示す。これより， $\alpha$ はに関 して直線的に減少していることが分かる. 図中には式(6) で定義され，以降の定式化で用いる近似直線とその決定 係数 $\mathrm{R}^{2}$ の結果を同色の数式で併記している. なお，（洪 水波形が完全に同じで）貯水容量がほぼ等しいCaseB と CaseEの結果は，近似直線も含めてほぼ一致している.

$$
\alpha=a N+b
$$

次に，式(6)の $a ， b$ を計算条件と関連づける事を考える. 横軸にダムの貯水容量 $V$ を総流入量で無次元化した $V \Sigma Q I N$ ，縦軸を $a ， b$ とした結果を図-9に示す，これよ り， $a ， b$ は VIQINに従ってほぼ直線的に減少しているこ とが分かる. 図中にはダムが無い場合 $(N=0)$ を考慮して, $a$ については式(7)で示寸比例関係の近似直線, bについて は $V \Sigma Q I N=0$ で1を通る式(8)のような近似直線をそれら の決定係数と併せて記載している. また，図中の $\mathrm{A} \sim \mathrm{E}$ の記号は計算Caseに対応している.

$$
\begin{gathered}
a=-0.9974(V / \Sigma Q I N) \\
b=-0.4818(V / \Sigma Q I N)+1
\end{gathered}
$$

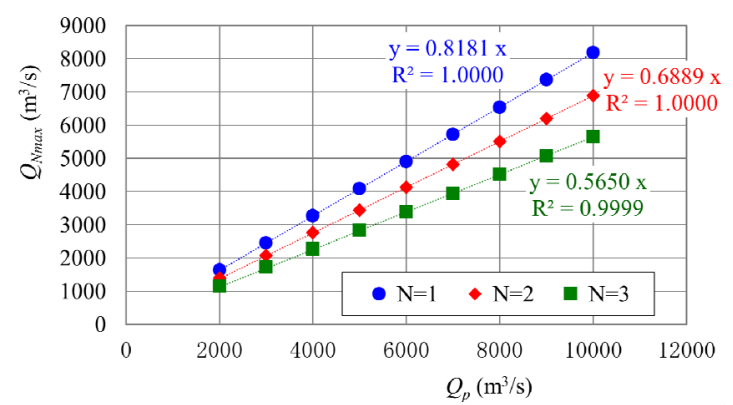

図-7 ピーク流量と最下流のダムの最大放流量の関係(CaseC)

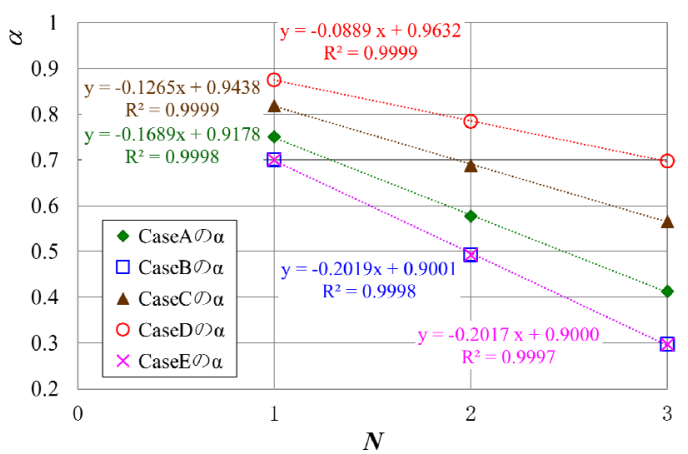

図-8 比例係数 $\alpha$ とダムの数 $N$ の関係

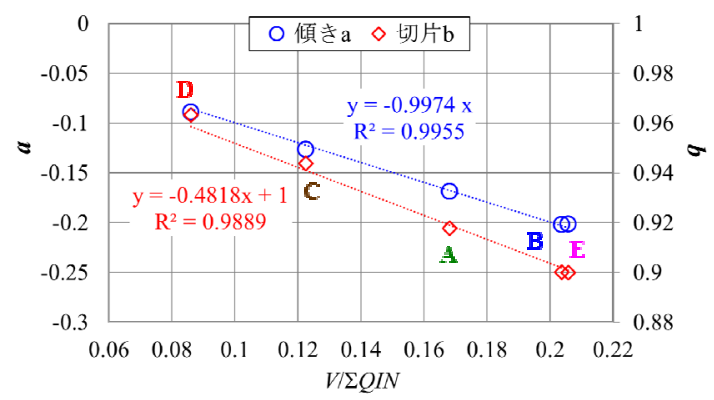

図-9 傾き $a$ および切片 $b$ と $V / \Sigma Q I N$ の関係

以上より, カスケード方式における最下流のダムからの 最大放流量 $Q_{\text {Nmax }}$ が次式のように表現される.

$$
\frac{Q_{N \max }}{Q_{p}}=-\left(\frac{V}{\Sigma Q I N}\right) N+\left\{1-0.4818\left(\frac{V}{\Sigma Q I N}\right)\right\}
$$

なお，近似式(7)中の傾きの絶対值0.9974はほぼ1である ことから，式(9)の評価式中では1と近似している。 これ は，図-7の ( $N$ の増加に伴う) 傾き $\alpha$ の変化率の絶対值と $V \Sigma Q I N$ が非常に良く一致していることに他ならない． また，V/IQINはそれ程大きな值を取らないことから， 図-9の右軸の值からも分かるようにbは0.9〜 1程度の值 であり，概算の評価と考えれば0.94程度，もしくは1の定 数と考えることも可能である.

最後に評価式(9)の精度を検証するために，実際に行っ た計算条件の $V, \Sigma Q I N を$ 代入して, 数值解析で得られた $Q_{\text {Nmax }} / Q_{p}$ の值と評価式から得られた推定值を比較した結 果を図-10に示す. 若干のばらつきは見られるものの, 式(9)が計算結果を十分に再現していることが理解される. ダムの形やハイドログラフの差異・変形の影響等がばら 


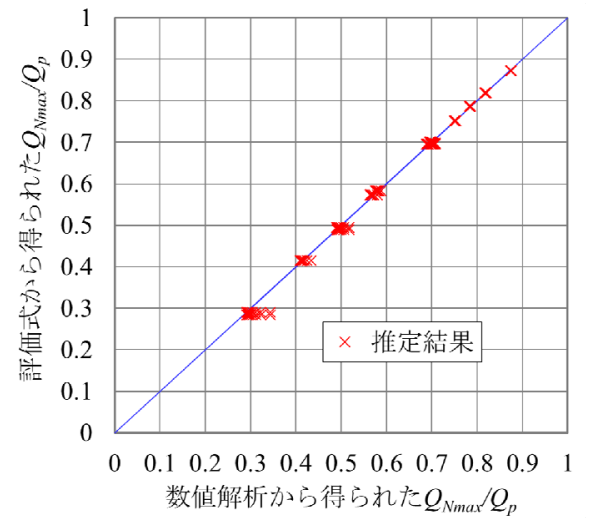

図-10 数值解析結果と評価式による推定結果の比較

つきの要因になっているものと考えられる. なお，式(9) は図-6中の越流型の近似直線に相当しており, 例えば CaseC5で比較すると, 実際の傾き-0.1241に対し式(9)で は-0.1225, 同様に切片は0.9384に対し0.9410とほぼ一致

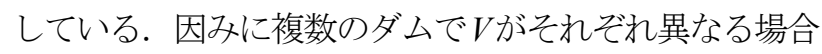
にも， $N=1$ とした式(9)を繰り返し用いることである程度 の概算は可能である. 一例として, 表-2の計算条件の組 み合わせで3つのダムが上流側から順にCaseB5, C5, D5で あった場合には，別途行った越流型の数值計算結果の $Q_{3 M a x}=2658\left(\mathrm{~m}^{3} / \mathrm{s}\right)$ に対し, 式(9)を3回用いることで $Q_{3 M a x}=2991\left(\mathrm{~m}^{3} / \mathrm{s}\right)$ が得られ，Vは最大で2.4倍になっている にも関わらず，13\%の誤差で近似結果が得られている. この場合，上流から下流まで $Q_{a}$ を一定としているものの， 常用洪水吐きの断面積はVに応じて異なっている.

\section{4. おわりに}

本研究では, 複数のダムが直列に配置された場合, 従 来の考えに基づいた非常用洪水吐きからの越流を（積極 的には）許容しないダム群と比較して, 山間部の上流側 のダムの越流を許容すること（カスケード方式）で，一 般的にはより重要となる下流側の洪水制御能力が顕著に 強化される機構について再度検討すると共に, 流水型ダ ム群を対象にした数值解析結果に基づいてその効果の定 量評価（経験式の導出）を行った.

その結果, 従来型の洪水制御では洪水のハイドログラ フを横に切る（だるま落としのような）イメージで洪水 のピークカットを行う際に, 一旦カットした洪水のピー クの後半部分を再びカットする2度手間な洪水処理を 行っていることが分かった. 一方, 越流型ではハイドロ グラフを縦に切るような洪水制御を行って貯水容量の使 用の2度手間を避けることで, 線形的に効率良く洪水の ピークカットを行っていることが分かった．また，今後 のカスケード方式の実用化に向けて，その洪水制御効果 を定量的に推定する簡便な評価式を導出した.

なお，カスケード方式の線形性を利用すれば，ダム (貯水型でも可) が設置された流域の温暖化適応策等を
考える場合, 今後の気候変化に伴って増加が見込まれる 洪水量に相当する貯水容量を河川の途中（通常は上流 側）に新規ダムとして確保寸れば良い事になる。した がって, カスケード方式は，治水効果を評価する上で経 済的に有利（従来手法に較べて治水効率が高い）という だけでなく, 評価そのものが著しく容易になるという原 理的メリットを有していることになる.

謝辞 : 本研究の一部は，JSPS科研費25420526および，環 境省環境研究総合推進費 [S-8-2(2)] の援助のもとに実 施された。ここに記して深甚なる謝意を表します.

\section{参考文献}

1) 日本学術会議, 国土・社会と自然災害分科会 : 提言 地球環 境の変化に伴う水災害への適応，2008.

2) T. Sumi: Designing and Operating of Flood Retention 'Dry' Dams in Japan and USA, Advances in Hydro-Science and Engineering, Vol.8, pp.1768-1777 (CD-ROM), 2008.

3) H. Oshikawa, A. Hashimoto, K. Tsukahara, and T. Komatsu: Impacts of Recent Climate Change on Flood Disaster and Preventive Measures, Journal of Disaster Research, Vol.3, No.2, pp.131-141, 2008.

4) 新田福美, 丸田満弘 : 西之谷ダム (流水型ダム) の概要につ いて，土木技術，65巻，2号，pp.65-67，2010.

5) 中川学 :「流水型穴あき式ダム」の安全性・環境影響を 問う, http://homepage3.nifty.com/nokki/bekkou.pdf

6) T. Sumi, S. A. Kantoush, and A. Shirai: Worldwide Flood Mitigation Dams: Operating and Designing Issues, Proceedings of the International Symposium on UFRIM, pp.101-106, September 2011.

7) 押川英夫, 三戸佑夏, 小松利光 : 流水型ダム群の洪水制御効 果に関寸る研究，河川技術論文集，第17巻，pp.317-322， 2011.

8) 押川英夫, 小松利光 : カスケード方式に基づく流水型ダム群 の洪水制御効果に関する研究, 土木学会論文集B1（水工 学) , Vol.68, No.4, pp. I_1489-I_1494, 2012.

9) 押川英夫, 三戸佑夏, 小松利光 : 直列配置された流水型ダム 群の洪水制御能力の検討, 土木学会論文集B1（水工学）,

Vol.69, No.4, pp. I_1633-I_1638, 2013.

10) 三戸佑夏，押川英夫，小松利光 : カスケード方式に基づく流 水型ダム群の洪水制御効果に関寸る実験的研究，土木学会論 文集B1（水工学）, Vol.69, No.4, pp.I_1639-I_1644, 2013.

11) 押川英夫, 小松利光 : カスケード方式に基づく直列配置され たダム群の洪水制御機構, 土木学会論文集B1（水工学）,

Vol.70, No.4, pp.I_1555-I_1560, 2014.

12) 押川英夫，今村友彦，小松利光 : 治水専用穴あきダムの河 道内遊水池としての洪水制御効果に関する研究，土木学会論 文集B1（水工学），Vol.67，No.4，pp.I_667-I_672，2011.

13) 土木学会 水理委員会 水理公式集改訂小委員会 : 水理公式 集 例題プログラム集，第 2 編 河川編，2002.

14) 土木学会 : 水理公式集 [平成11年版］，713p., 1999. 